\title{
Analisis Faktor Penyebab Minimnya Minat Masyarakat Kabupaten Rejang Lebong Menjadi Mahasiswa Prodi Ekonomi Syariah IAIN Curup
}

\author{
Muhammad Istan, Ratih Komala Dewi \\ Institut Agama Islam Negeri (IAIN) Curup, Indonesia \\ muhammadistan@iaincurup.ac.id
}

\begin{abstract}
Sharia Economic Study Program of Curup State Islamic University (IAIN Curup) has obtained the Operating Permit from 2016. Based on the data obtained by students enrolled in the Islamic economics study program, only a minority came from Rejang Lebong district, while the majority came from outside the region. The purpose of this study is to determine whether there is an influence of knowledge about the institution towards the lack of community interest in Rejang Lebong Regency to study at the Curriculum of Islamic Studies Program IAIN Curup. The research data collection methods were questionnaires and interviews, with 334 respondents from 12th grade high school students in the Rejang Lebong district selected randomly and analyzed using the Fish Bone method. The results showed that the low interest of the community to continue their education to the Curriculum of Islamic Studies program IAIN Curup due to lack of knowledge about the existence and the existence of scholarships, supporting facilities, qualifications of lecturers in the Curriculum of Islamic Studies Program IAIN Curup, lack of information dissemination about the process of admission of new students in the Economic Study Program Syariah IAIN Curup, not yet evenly distributed participants of the vision and mission of IAIN Curup Sharia Economic Study Program.
\end{abstract}

Keywords: Mix, Marketing, Economy, Sharia, Fish Bone.

\begin{abstract}
Abstrak
Program studi Ekonomi Syariah Institut Agama Islam Negeri (IAIN) Curup telah mendapat izin penyelenggaraan dari tahun 2016. Berdasarkan data yang diperoleh mahasiswa yang terdaftar pada program studi ekonomi syariah tersebut hanya minoritas yang berasal dari kabupaten Rejang Lebong, sedangkan mayoritasnya berasal dari luar daerah. Tujuan penelitian ini adalah untuk mengetahui ada tidaknya pengaruh pengetahuan mengenai kelembagaan terhadap minimnya minat masyarakat kabupaten Rejang
\end{abstract}

FOKUS : Jurnal Kajian Keislaman dan Kemasyarakatan Vol. 5, No. 1, 2020

LPPM Institut Agama Islam Negeri (IAIN) Curup - Bengkulu

p-ISSN 2548-334X, e-ISSN 2548-3358

DOI: $10.29240 /$ jf.v5i1.1480 
Lebong untuk kuliah pada Program Studi Ekonomi Syariah IAIN Curup. Metode pengumpulan data penelitian yaitu kuesioner dan wawancara, dengan responden 334 orang siswa kelas 12 SMA sekabupaten Rejang Lebong yang dipilih random dan dianalisis dengan metode Fish Bone. Hasil Penelitian menunjukkan bahwa rendahnya minat masyarakat untuk melanjutkan pendidikan ke program studi Ekonomi Syariah IAIN Curup karena kurangnya pengetahuan tentangkeberadaan serta adanya beasiswa, fasilitas penunjang, kualifikasi dosen pada Program Studi Ekonomi Syariah IAIN Curup, kurang tersebarnya informasi tentang proses penerimaan mahasiswa baru Program Studi Ekonomi Syariah IAIN Curup, belum meratanya peserta sosialisasi Visi dan Misi Program Studi Ekonomi Syariah IAIN Curup.

Kata kunci: Bauran, Pemasaran, Ekonomi, Syariah, Fish Bone.

\section{Pendahuluan}

Perguruan tinggi harus memiliki strategi untuk dapatmempertahankan keberadaannya, supaya dapat bersaing dengan perguruan tinggiyang lain. Hal ini dapat dicapai dengan mengembangkan dan menyajikan bauranpemasaran yang diarahkan pada pasar sasaran yang dipilih. Bauran pemasaran yangterkait dengan jasa, meliputi produk, harga, promosi, lokasi, proses, orang, sertapelayanan.

Lupiyoadi dan Hamdani (Wijaya, N.Q, 2016) ${ }^{1}$ menjelaskan bahwa beberpa karakteristik jasa dalam perguruan tinggi yang menjadi perhatian diantarannya :

1. Perguruan Tinggi tergolong ke dalam pureservice atau dikenal dengan kelompok jasa murni.

2. Dalam prosesnya, jasa yang diberikan harus ada penerima jasa (mahasiswa)

3. Komunikasi antara pemberi dan penerima jasa harus intensif (High Contact System)

4. Hubungan dengan pelanggan. Pada prosesnya, bauran pemasaran pada lembaga pendidikan tinggi sesuai dengan karakteristik dan kualifikasi digolongkan menjadi:

a. Program (Proses dan pengembangan program)

\footnotetext{
${ }^{1}$ Nur Quodri Wijaya, "Strategi Untuk Meningkatkan Minat Mahasiswa Baru Studi Pada Universitas Wiraraja Sumenep," Journal of Chemical Information and Modeling, 2013, https://doi.org/10.1017/CBO9781107415324.004.
} 
b. Price (harga)

c. Delivery system dan Physical facilities

\section{Communication}

Bauran pemasaran jasa memiliki pengaruh yang kuat terhadap keberhasilan suatu strategi bauran pemasaran, karena strategi bauran pemasaranmemiliki keterkaitan terhadap kebijakan strategi pemasaran. Dalam memahamipemasaran jasa pendidikan tinggi, strategi yang diterapkan tidak terlepas daristrategi bauran pemasaran. Strategi bauran pemasaran dalam hubungannya denganpemasaran jasa Pendidikan Tinggi tidak terlepas dari produk (Program studi), harga (biaya pendidikan), promosi, lokasi, orang, proses, dan pelayanan.

Dalam hal ini, Program Studi harus memahami produkapa yang diinginkan dan bermanfaat dari sudut pandang pelanggan (mahasiswa), sepertimanfaat produk yang dapat memenuhi keinginan dan kepuasan mahasiswa. Kemudian tangible offer seperti feature, kualitas, arsitektur gedung, halaman kampus dan lingkungan yang mendukung fungsi pendidikan dari perguruan tinggitersebut.

Institut Agama Islam Negeri (IAIN) Curup membuka program studi Ekonomi Syariah berdasarkan Izin Penyelenggaraan dari Dirjen Pendidikan Islam Nomor 3514 Tahun 2016 tanggal 21 Oktober 2016. Penerimaan mahasiswa angkatan pertama dimulai pada tahun akademik 2017-2108. Pendaftar pada periode pertama sebanyak 60 orang, namun yang mengikuti tes 58 orang. Mahasiswa yang lulus dan mendaftar ulang sebanyak 49 orang. Kemudian pada tahun akademik 2018-2019 jumlah pendaftar 75 orang, dan mengikuti tes 65 orang. Adapun tabulasi data mahasiswa pada Program Studi Ekonomi Syariah tersebut dapat dapat di sajikan dalam grafik 1 beriikut: 
Grafik 1. Tabulasi data mahasiswa Program Studi Ekonomi Syariah 2018

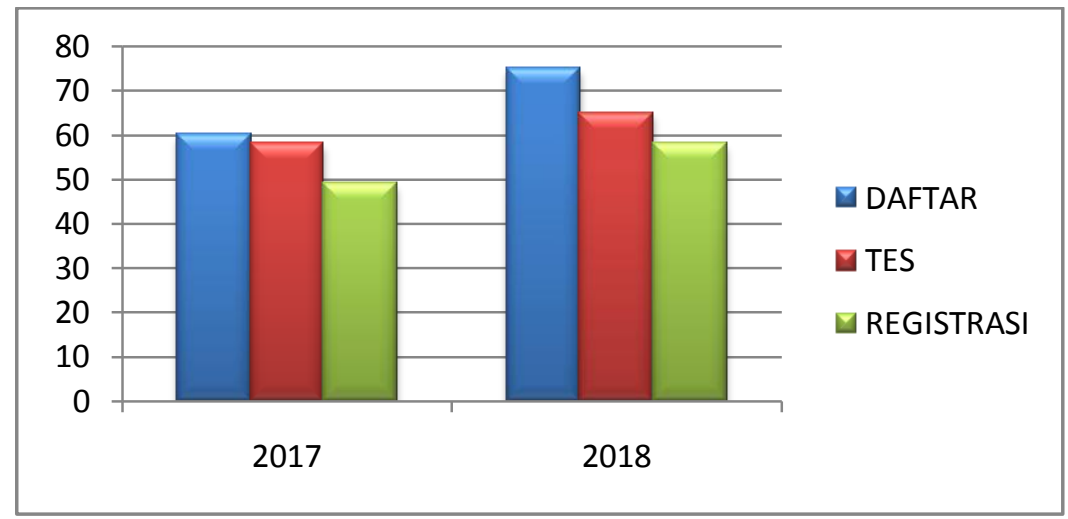

Grafik 1 menunjukkan penurunan angka mahasiswa yang melakukan registrasi setiap tahun jika dibanding dengan jumlah mahasiswa yang mendaftar pada Program Studi Ekonomi Syariah. Selain itu juga, mahasiswa yang terdaftar pada program studi ekonomi syariah tersebut bukan berasal dari kabupaten Rejang Lebong semuanya, melainkan kebanyakan berasal dari luar daerah. Adapun rincian daerah asal mahasiswa Program Studi Ekonomi Syariah IAIN Curup disajikan dalam grafik berikut :

Grafik 2 Tabulasi Daerah Asal mahasiswa Prodi ES 2017 - 2018

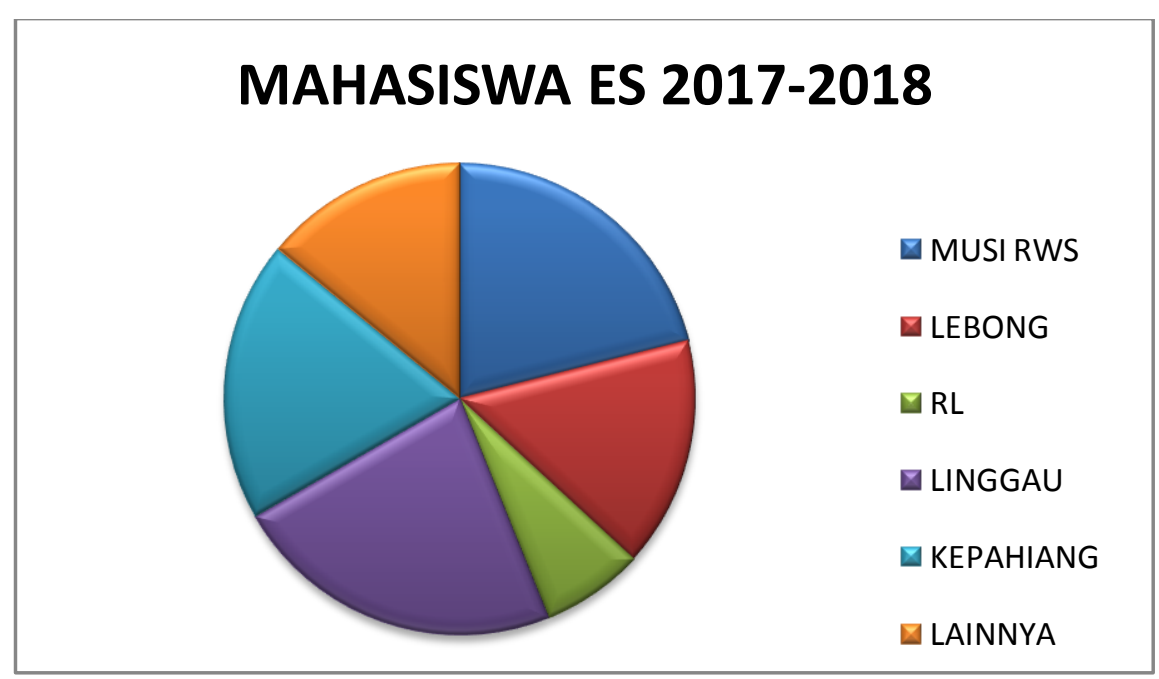

Grafik 2 menunjukkan bahwa mahasiswa Program Studi Ekonomi Syariah IAIN Curup 21\% berasal dari Musi Rawas, 16\% dari Kabupaten Lebong, 7\% dari Kabupaten Rejang Lebong, 23\% dari Linggau, 19\% dari Kabupaten Kepahiyang dan $14 \%$ dari kota lainnya. Setelah dipetakan 
diperoleh bahwa hanya 7\% mahasiswa yang berasal dari Kabupaten Rejang Lebong sisanya berasal dari luar Kabupaten Rejang Lebong.Hal tersebut membuat peneliti tertarik untuk mengkaji Pengaruh Strategi Bauran Promosi Terhadap Minat Masyarakat Kabupaten Rejang Lebong untuk menjadi mahasiswa IAIN Curup Khususnya Prodi Ekonomi Syariah.Berdasarkan latar belakang yang diuraikan diatas, maka pertanyaan penelitian yaitu "Apa yang menjadi faktor penyebab rendahnya minat masyarakat Kabupaten Rejang Lebong menjadi Mahasiswa pada Program Studi Ekonomi Syariah IAIN Curup?"

\section{Pemasaran Jasa}

Kotler mengemukakan perguruan tinggi perlu mengetahui pelayanan yang telah diberikan kepada mahasiswanya, sehingga mahasiswa merasa puas. Dalam hal ini bisa berupa manajemen yang rapi, kualitas proses pembelajaran, fasilitas yang diberikan, dan layanan adminstrasi. Perguruan tinggi harus memiliki strategi untuk dapat mempertahankan keberadaannya, supaya dapat bersaing dengan perguruan tinggi yang lain ${ }^{2}$. Hal ini dapat dicapai dengan mengembangkan dan menyajikan bauran pemasaran yang diarahkan pada pasar sasaran yang dipilih. Bauran pemasaran yang terkait dengan jasa, meliputi produk, harga, promosi, lokasi, proses, orang, serta pelayanan.

Pemasaran jasa diartikan sebagai melakukan sesuatu bagi otang lain, produk yang ditawarkan tidak berwujud dan komprehensif ${ }^{3}{ }^{4}$ Namun demikian, tidaklah mudah dalam mencari pdanan kata dalam bahasa Indonesia yang sesuai untuk istilah tersebut. Sekurang-kurangnya ada tiga kata yang mencerminkan istilah tersebut yaitu jas, layanan dan service. Pemasaran jasa ini berhubungan dengan produk tidak berwujud fisik (intangible) yang bergerak pada sector industri seperti pendidikan, asuransi, kesehatan, telekomunikasi, perbankan, dan lainnya

${ }^{2}$ Kotler, Manajemen Pemasaran Jilid 2, Penerbit Erlangga, 2013.

${ }^{3}$ Fandy Tjiptono, "Pemasaran Jasa - Prinsip, Penerapan, Dan Penelitiab," in 1, 2014.

${ }^{4}$ Fandy Tjiptono and Fandy Tjiptono, "Service Management: Mewujudkan Layanan Prima / Fandy Tjiptono," ,Service Management: Mewujudkan Layanan Prima / Fandy Tjiptono, 2012, https://doi.org/10.1519/JPT.0b013e31826e7d33. 


\section{Promosi.}

Aktivitas dalam suatu perusahaan sangat banyak dan kompleks, tentu dengan banyaknya aktivitas yang dilakukan tidak hanya menghasilkan produk atau jasa, menetapkan harga, dan menjual produk atau jasa, tetapi banyak aktivitas lainnya yang saling berkaitan satu dengan lainnya, sehingga diperlukan sinergitas antar unit yang ada dalam perusahaan ${ }^{5}$. Sementara Swasta $^{6}$ mengungkapkan arti promosi adalah suatu upaya atau kegiatan perusahaan dalam mempengaruhi "konsumen aktual" maupun "konsumen potensial" agar mereka mau melakukan pembelian terhadap produk yang ditawarkan, saat ini atau dimasa yang akan datang.

Kemudian Jones ${ }^{7}$, promosi adalah kombinasi strategi yang paling baik dari variabel-variabel periklanan, penjualan personal dan alat promosi yang lain, yang semuanya direncanakan untuk mencapai tujuan program penjualan. Sedangkan menurut $\operatorname{Irwan}^{8}$, promosi adalah usaha yang dilakukan agar calon pembeli memperhatikan kepada usaha, barang atau jasa yang ditawarkan untuk kemudian mendorongnya untuk membeli.

\section{Bauran Pemasaran}

Wariki et al., ${ }^{9}$ mengemukakan bauran promosi merupakan ramuan yang terdiri dari iklan, penjualan pribadi, promosi penjualan dan hubungan masyarakat yang dipergunakan untuk mencapai tujuan pemasaran. Adapun bauran promosi yang dimaksud berupa promosi penjualan, periklanan,

${ }^{5}$ Moh Mukery Susilo, Heri; Haryono, Andi Tri; W, “Analisis Pengaruh Harga, Kualitas Pelayanan, Promosi, Dan Kepercayaan Terhadap Kepuasan Konsumen Dengan Keputusan Berkunjung Sebagai Variabel Intervening Di Hotel Amanda Hills Bandungan," Maharaja Agrasen Institute of Management and Technology Journal of IT \& Management, 2018.

${ }^{6}$ Irawan Swastha, Basu, Manajemen Pemasaran Modern., Liberty, Yogyakarta., 2014, https://doi.org/10.1017/CBO9781107415324.004.

${ }^{7}$ John Philip Jones, “Advertising and Promotion," in Encyclopedia of International Media and Communications, 2003, https://doi.org/10.1016/B0-12-387670-2/00002-9.

${ }^{8}$ Agus Irawan, "Analisis Pengaruh Bauran Pemasaran Jasa Terhadap Keputusan Memilih Program Studi (Studi Pada Jurusan Akuntansi Dan Jurusan Administrasi Bisnis Di Politeknik Negeri Banjarmasin)," Jurnal Wawasan Manajemen, 2014.

${ }^{9}$ Grace Wariki, Lisbeth Mananeke, and Hendra Tawas, "Pengaruh Bauran Promosi, Persepsi Harga Dan Lokasi Terhadap Keputusan Pembelian Dan Kepuasan Konsumen Pada Perumahan Tamansari Metropolitan Manado," Jurnal Riset Ekonomi, Manajemen, Bisnis Dan Akuntansi, 2015, https://doi.org/10.35794/emba.v3i2.9286. 
penjualan tatap muka, hubungan masyarakat dan publisitas serta pemasaran langsung.

\section{Indikator Bauran Jasa Perguruan Tinggi}

Parasuraman et al., ${ }^{10}$ mengemukakan beberapa unsur yang dalam bauran pemasaan terdapat tujuh unsur yang lazin dikenal dengan $7 \mathrm{P}$ yang dibagi menjadi 4P yaitu product (produk) tentang jasa apa saja yang ditawarkan; price (biaya), strategi dalam penentuan harga/biaya; place (lokasi), tempat jasa yang akan diberikan; promotion (promosi) tentang promosi yang diberikan kepada pelanggan. Selanjutnya unsur 3P adalah people (SDM) tentang kualitas, kompetensi serta kualifikasi yang dimiliki para pemberian jasa. Physical evidence (bukti fisik) tentang sarana dan prasarana yang dimilki, yang terakhir process tentang bagaimana manajerial layanan pembelajaran yang diberikan.

Tabel 1. Indikator Penelitian

\begin{tabular}{|c|c|c|c|}
\hline No. & Dimensi & Variabel Penelitian & Indikator \\
\hline \multirow[t]{3}{*}{1.} & \multirow{3}{*}{ Product } & Keberadaan Prodi & Pengetahuan adanya Prodi \\
\hline & & Kurikulum Prodi & Kompetensi \\
\hline & & Reputasi Prodi & Akreditasi \\
\hline \multirow[t]{3}{*}{2.} & \multirow[t]{3}{*}{ Price } & Biaya Pendidikan & Rincian Biaya \\
\hline & & Diskon & Beasiswa \\
\hline & & Pembayaran & SOP Pembayaran \\
\hline \multirow[t]{2}{*}{3.} & \multirow[t]{2}{*}{ People } & $\begin{array}{l}\text { Tenaga } \\
\text { Kependidikan }\end{array}$ & $\begin{array}{l}\text { Kompetensi Layanan } \\
\text { Administrasi Prodi }\end{array}$ \\
\hline & & Tenaga Dosen & Kualifikasi Dosen \\
\hline \multirow[t]{2}{*}{4.} & \multirow[t]{2}{*}{ Place } & Lokasi & $\begin{array}{l}\text { Lokasi dekat dengan Pusat } \\
\text { Kota }\end{array}$ \\
\hline & & Transportasi & Angkutan darat \\
\hline \multirow[t]{2}{*}{5.} & \multirow[t]{2}{*}{ Promotion } & Periklanan & Spanduk, Brosur \\
\hline & & Sales Promotion & Sosialisasi \\
\hline \multirow[t]{2}{*}{6.} & \multirow{2}{*}{$\begin{array}{l}\text { Physical } \\
\text { Evidence }\end{array}$} & Bangunan & Gedungperkuliahan \\
\hline & & Fasilitas Penunjang & $\begin{array}{l}\text { Laboratorium, } \\
\text { perpustakaan, Masjid, LCD }\end{array}$ \\
\hline 7. & Process & Pelayanan & Proses seleksi \\
\hline
\end{tabular}

${ }^{10}$ A. Parasuraman, Valarie A. Zeithaml, and Leonard L. Berry, "A Conceptual Model of Service Quality and Its Implications for Future Research," Journal of Marketing, 1985, https://doi.org/10.2307/1251430. 


\begin{tabular}{|l|l|l|}
\hline & $\begin{array}{l}\text { Penerimaan } \\
\text { Mahasiswa Baru }\end{array}$ & \\
\hline
\end{tabular}

\section{Penelitian Terdahulu}

Kalsum, E.A. ${ }^{11}$ melakukan penelitian terhadap 30 orang responden sehingga diperoleh hasil penelitian berupa secara simultan diperoleh bahwa produk, harga, promosi, tempat, orang,proses, dan pelayanan, secara bersama-sama berpengaruh terhadap keputusan mahasiswa memilih pada Fakultas Ekonomi Universitas AlAzhar Medan.

Mutmainah,Siti ${ }^{12}$ melakukan penelitian terhadap 60 orang responden dengan hasil penelitian berupa periklanan, personal selling, promosi penjualan, publisitas dan promosi penjualan berpengaruh terhadap minat partisipasi masyarakat.

Gultom, D.K, dkk ${ }^{13}$ melakukan penelitian terhadap 89 orang responden dengan hasil penelitian berupa Bauran pemasaran jasa (Produk, Biaya Pendidikan, Tempat, Proses, Orang, Bukti fisik) dan Kualitas Pelayanan (Bukti langsung, Kehandalan, Ketanggapan, Jaminan, Dan Empati) berpengaruh terhadap kepuasan mahasiswa.

\section{Metode Penelitian}

Metode yang digunakan adalah deskriptif evaluatif.Penelitian yang dilakukan ini merupakan penelitian yang menggunakan pendekatan kualitatif. Menurut ${ }^{14}$ penelitian kualitatif berakar pada latar alamiah sebagai keutuhan, yang mengandalkan manusia sebagai alat penelitian. Beliau memanfaatkan metode kualitatif analisis data secara induktif, ia mengarahkan sasaran penelitian pada usaha menemukan teori dari dasar,

${ }^{11}$ Eka Umi Kalsum, "Pengaruh Strategi Bauran Pemasaran Terhadap Keputusan Mahasiswa Memilih Perguruan Tinggi Swasta Di Medan," Pengaruh Strategi Bauran Pemasaran Terhadap Keputusan Mahasiswa Memilih Perguruan Tinggi Swasta Di Medan, 2010.

${ }^{12}$ Luthfina Ariyani, R. Rizki Amalia, and Yurna Lisa, "Pengaruh Personal Selling Dan Periklanan Terhadap Volume Penjualan Produk Bepang Ud.Diah, Kecamatan Pelaihari," Jurnal Teknologi Agro-Industri, 2017, https://doi.org/10.34128/jtai.v4i1.48.

${ }^{13}$ B. Sembiring D. Gultom P. Ginting, "Pengaruh Bauran Pemasaran Jasa Dan Kualitas Pelayanan Terhadap Mahasiswa Program Studi Manajemen Fakultas Ekonomi Universitas Muhammadiyah Sumatera Utara," Manajemen Dan Bisnis, 2014.

${ }^{14}$ Lexy J. Moleong, "Metodologi Penelitian Kualitatif (Edisi Revisi)," in PT. Remaja Rosda Karya, 2017. 
bersifat deskriptif yang lebih mementingkan proses dari pada hasil dan membatasi studi tentang fokus, memilih seperangkat kriteria untuk menulis keabsahan data, rancangan penelitian bersifat sementara dan hasil pemelitian disepakati oleh peneliti dan subjek penelitian.

Pada penelitian ini subjek penelitian adalah para pelajar kelas 3 SMA sederajat pada Kabupaten Rejang Lebong. Adapun populasi penelitian sebanyak 2026 orang yang tersebar pada seluruh kecamatan yang ada pada Kabupaten Rejang Lebong.Berdasarkan rumus Slovin untuk mendapatkan sampel dari populasi dengan menggunakan rumus sebagai berikut:

$$
\begin{aligned}
& n=\frac{N}{\left(N x d^{2}\right)+1} \\
& \text { dimana, } \\
& \mathrm{n}=\text { sampel } \\
& \mathrm{N}=\text { populasi } \\
& \mathrm{d}=\text { sign } 0.05 \\
& n=\frac{2026}{\left(2026 \times\left(0.05^{2}\right)\right)+1}=334 \text { orang }
\end{aligned}
$$

Pada penelitian ini menggunakan data primer yang diperoleh secara langsung dilapangan yaitu berupa hasil jawaban kuesioner dari 334 responden. Setelah itu cross check dengan mewawancarai 28 responden yang mewakili seluruh sampel penelitian.

Analisis data yang digunakan adalah analisis fishbone diagram atau yang lebih dikenal dengan diagram tulang ikan yang awalnya diperkenalkan oleh Dr. Kaoru Ishikawa. Tague ${ }^{15}$ menjelaskan bahwa fish bone diagram ini digunakan untuk mengidentifikasi beberapa penyebab masalah dari suatu issu yang diperbincangkan. Adapun langkah langkah membuat fish bone diagram $^{16}$ yaitu :

1. Menyepakati apa yang menjadi pernyataan suatu masalah

2. Menyepakati kategori yang akan dianalisis

3. Melakukan brainstorming untuk menentukan penyebab utama suatu masalah

\footnotetext{
${ }^{15}$ Christiana Evy Tri Widyahening, "Penggunaan Teknik Pembelajaran Fishbone Diagram," Jurnal Komunikasi 2018, https://doi.org/https://doi.org/10.32585/jkp.v2i1.59.

${ }^{16}$ Tague,N.R.(2005).Thequalitytoolbox.(2thed.).Milwaukee,Wisconsin:ASQQualit yPress.
} 
130 | FOKUS : Jurnal Kajian Keislaman dan Kemasyarakatan Vol. 5, No. 1, 2020

4. Mengkaji dan menyepakati penyebab yang paling mungkin.

\section{Hasil dan Pembahasan}

Berdasarkan pengolahan data yang diperoleh dalam penelitian ditabulasikan dalam tabel berikut ini :

Tabel 2. Tabulasi Hasil Pengolahan Data Penelitian

\begin{tabular}{|c|c|c|c|c|c|}
\hline \multirow{2}{*}{ No } & \multirow{2}{*}{ Pertanyaan } & \multicolumn{2}{|c|}{ Ya } & \multicolumn{2}{|c|}{ Tidak } \\
\hline & & Jumlah & $\%$ & Jumlah & $\%$ \\
\hline \multicolumn{6}{|c|}{ Product } \\
\hline 1 & $\begin{array}{l}\text { Apakah anda mengetahui keberadaan Program } \\
\text { Studi Ekonomi Syariah IAIN Curup? }\end{array}$ & 304 & $91 \%$ & 30 & $9 \%$ \\
\hline 2 & $\begin{array}{l}\text { Apakah anda mengetahui kurikulum Program } \\
\text { Studi Ekonomi Syariah IAIN Curup? }\end{array}$ & 286 & $86 \%$ & 48 & $14 \%$ \\
\hline 3 & $\begin{array}{l}\text { Apakah anda mengetahui Akreditasi Program } \\
\text { Studi Ekonomi Syariah IAIN Curup? }\end{array}$ & 291 & $87 \%$ & 43 & $13 \%$ \\
\hline \multicolumn{6}{|c|}{ Price } \\
\hline 4 & $\begin{array}{l}\text { Apakah anda mengetahui Rincian Biaya } \\
\text { Program Studi Ekonomi Syariah IAIN Curup? }\end{array}$ & 290 & $87 \%$ & 44 & $13 \%$ \\
\hline 5 & $\begin{array}{l}\text { Apakah anda mengetahui Beasiswa yang ada } \\
\text { pada Program Studi Ekonomi Syariah IAIN } \\
\text { Curup? }\end{array}$ & 297 & $89 \%$ & 37 & $11 \%$ \\
\hline 6 & $\begin{array}{l}\text { Apakah anda mengetahui Prosedur } \\
\text { Pembayaran Akreditasi Program Studi } \\
\text { Ekonomi Syariah IAIN Curup? }\end{array}$ & 276 & $83 \%$ & 58 & $17 \%$ \\
\hline \multicolumn{6}{|c|}{ People } \\
\hline 7 & $\begin{array}{l}\text { Apakah anda mengetahui Kompetensi } \\
\text { Layanan Administrasi Program Studi Ekonomi } \\
\text { Syariah IAIN Curup? }\end{array}$ & 284 & $85 \%$ & 50 & $15 \%$ \\
\hline 8 & $\begin{array}{l}\text { Apakah anda mengetahui kualifikasi dosen } \\
\text { pada Program Studi Ekonomi Syariah IAIN } \\
\text { Curup? }\end{array}$ & 324 & $97 \%$ & 10 & $3 \%$ \\
\hline \multicolumn{6}{|c|}{ Place } \\
\hline 9 & $\begin{array}{l}\text { Apakah lokasi Program Studi Ekonomi } \\
\text { Syariah IAIN Curup berada di tengah kota? }\end{array}$ & 280 & $84 \%$ & 54 & $16 \%$ \\
\hline 10 & $\begin{array}{l}\text { Apakah transportasi di lingkungan IAIN } \\
\text { Curup (Dusun Curup/ Simpang Lebong) } \\
\text { khususnya Prodi Ekonomi Syariah Lancar? }\end{array}$ & 28 & $8 \%$ & 306 & $92 \%$ \\
\hline \multicolumn{6}{|c|}{ Promotion } \\
\hline 11 & $\begin{array}{l}\text { Apakah anda pernah melihat Spanduk } \\
\text { Program Studi Ekonomi Syariah IAIN Curup? }\end{array}$ & 303 & $91 \%$ & 31 & $9 \%$ \\
\hline 12 & $\begin{array}{l}\text { Apakah anda pernah mendapat brosur Program } \\
\text { Studi Ekonomi Syariah IAIN Curup? }\end{array}$ & 278 & $83 \%$ & 56 & $17 \%$ \\
\hline 13 & $\begin{array}{l}\text { Apakah anda pernah menjadi peserta } \\
\text { sosialisasi visi dan misi Program Studi } \\
\text { Ekonomi Syariah IAIN Curup? }\end{array}$ & 320 & $96 \%$ & 14 & $4 \%$ \\
\hline
\end{tabular}


M Istan, R K Dewi: Analisis Faktor Penyebab Minimnya Minat Masyarakat ... | 131

\begin{tabular}{|c|l|c|c|c|c|}
\hline 14 & $\begin{array}{l}\text { Apakah anda mengetahui gedung kuliah } \\
\text { Program Studi Ekonomi Syariah IAIN Curup? }\end{array}$ & 268 & $80 \%$ & 66 & $20 \%$ \\
\hline 15 & $\begin{array}{l}\text { Apakah anda mengetahui fasilitas penunjang } \\
\text { perkuliahan pada Program Studi Ekonomi } \\
\text { Syariah IAIN Curup? }\end{array}$ & 319 & $96 \%$ & 15 & $4 \%$ \\
\hline Process & $\begin{array}{l}\text { Apakah anda mengetahui proses seleksi } \\
\text { penerimaan mahasiswa baru pada IAIN Curup } \\
\text { khususnya Program Studi Ekonomi Syariah? }\end{array}$ & 272 & $81 \%$ & 62 & $19 \%$ \\
\hline
\end{tabular}

Berdasarkan tabel 1 ditinjau dari 7 indikator dalam penelitian ini yaitu product (produk), price (harga), people (SDM), place (tempat), promotion (promosi), phisical eviden (sarana dan prasarana) dan process (proses) akan dijelaskan lebih rinci sebagai berikut:

\section{Product (Produk)}

Ditinjau dari hasil pengolahan data penelitian pada tabel 4.1 diatas diperoleh nilai prosentase yang paling tinggi pada indikator product (produk) yaitu $91 \%$ atau sebanyak 304 dari 334 responden. Hal tersebut berindikasi bahwa, masyarakat Kabupaten Rejang Lebong dalam hal ini pelajar kelas 3 SMA di kawasan Rejang Lebong tidak mengetahui keberadaan prodi Ekonomi Syariah IAIN Curup.

\section{Price (Harga)}

Ditinjau dari hasil pengolahan data penelitian pada tabel 4.1 diatas diperoleh nilai prosentase yang paling tinggi pada indikator price (harga) yaitu 89\% atau sebanyak 297 dari 334 responden. Hal tersebut berindikasi bahwa, masyarakat Kabupaten Rejang Lebong dalam hal ini pelajar kelas 3 SMA di kawasan Rejang Lebong tidak mengetahui Beasiswa yang ada pada Program Studi Ekonomi Syariah IAIN Curup.

\section{People (SDM)}

Ditinjau dari hasil pengolahan data penelitian pada tabel 4.1 diatas diperoleh nilai prosentase yang paling tinggi pada indikator people (SDM) yaitu 97\% atau sebanyak 324 dari 334 responden. Hal tersebut berindikasi bahwa, masyarakat Kabupaten Rejang Lebong dalam hal ini pelajar kelas 3 SMA di kawasan Rejang Lebong tidak mengetahui kualifikasi dosen pada Program Studi Ekonomi Syariah IAIN Curup. 


\section{Place (Tempat)}

Ditinjau dari hasil pengolahan data penelitian pada tabel 4.1 diatas diperoleh nilai prosentase yang paling tinggi pada indikator Place (Tempat) yaitu 92\% atau sebanyak 306 dari 334 responden. Hal tersebut berindikasi bahwa, transportasi di lingkungan IAIN Curup khususnya Prodi Ekonomi Syariah cukup Lancar.

\section{Promotion (Promosi)}

Ditinjau dari hasil pengolahan data penelitian pada tabel 4.1 diatas diperoleh nilai prosentase yang paling tinggi pada indikator people (SDM) yaitu $96 \%$ atau sebanyak 320 dari 334 responden. Hal tersebut berindikasi bahwa, masyarakat Kabupaten Rejang Lebong dalam hal ini pelajar kelas 3 SMA di kawasan Rejang Lebong tidak pernah menjadi peserta sosialisasi visi dan misi Program Studi Ekonomi Syariah IAIN Curup.

\section{Phisical Eviden (Sarana dan Prasarana)}

Ditinjau dari hasil pengolahan data penelitian pada tabel 4.1 diatas diperoleh nilai prosentase yang paling tinggi pada indikator product (produk) yaitu $96 \%$ atau sebanyak 319 dari 334 responden. Hal tersebut berindikasi bahwa, masyarakat Kabupaten Rejang Lebong dalam hal ini pelajar kelas 3 SMA di kawasan Rejang Lebong tidak tau tentang fasilitas penunjang perkuliahan pada Program Studi Ekonomi Syariah IAIN Curup.

\section{Process (Proses)}

Ditinjau dari hasil pengolahan data penelitian pada tabel 4.1 diatas diperoleh nilai prosentase yang paling tinggi pada indikator product (produk) yaitu $81 \%$ atau sebanyak 272 dari 334 responden. Hal tersebut berindikasi bahwa, masyarakat Kabupaten Rejang Lebong dalam hal ini pelajar kelas 3 SMA di kawasan Rejang Lebong tidak tau tentang proses seleksi penerimaan mahasiswa baru pada IAIN Curup khususnya Program Studi Ekonomi Syariah.

Selanjutnya dalam penelitian ini dilakukan wawancara kepada 28 responden yang tersebar di 15 kecamatan Rejang Lebong untuk cross check dalam rangka menggali lebih lanjut mengenai ketidak tahuan para pelajar tentang berbagai hal yang berhubungan $7 \mathrm{P}$ di atas. 


\section{Analisis Fish Bone}

Berdasarkan pembahasan dari pengolahan data penelitian di atas kemudian di lanjutkan dengan menganalisis fish bone yang dapat di visualisasikan sebagai berikut:

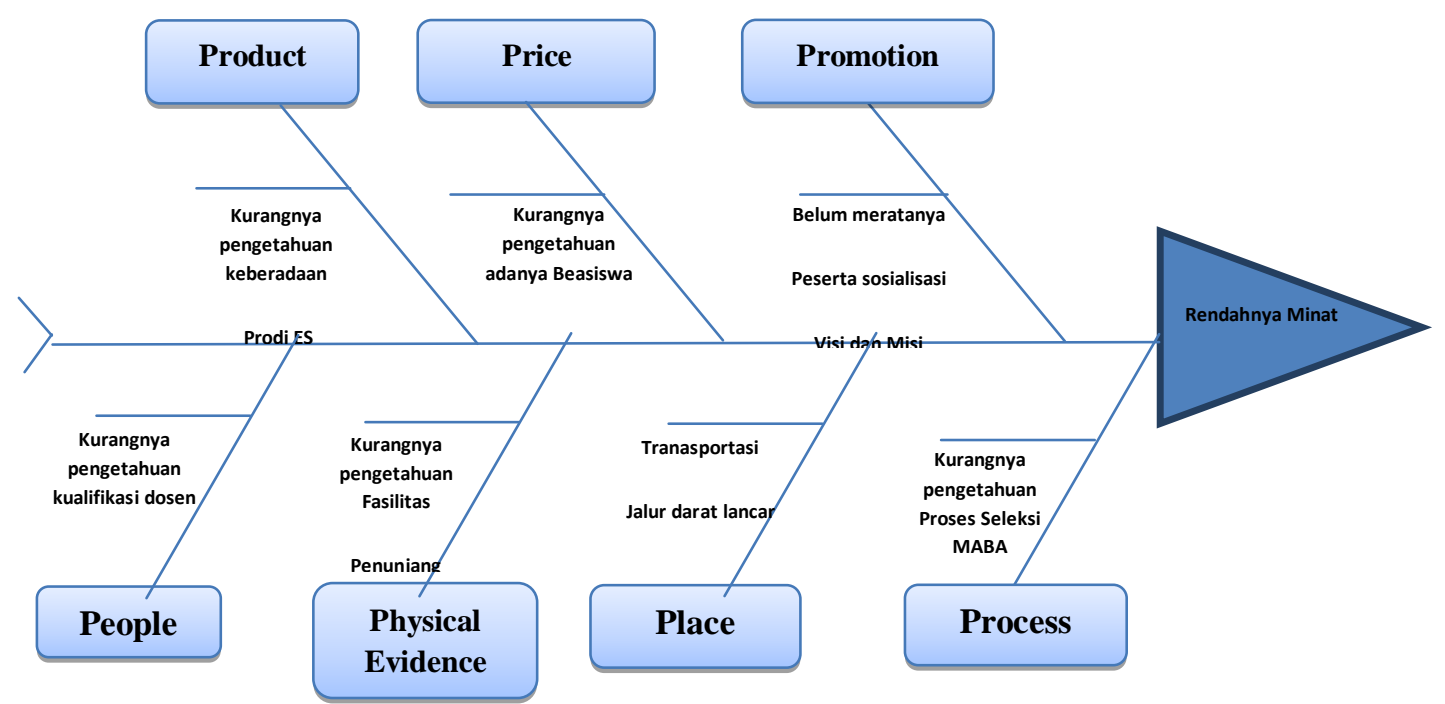

Gambar 1 Visualisasi Analisis Fish Bone

Berdasarkan gambar 1, diperoleh penyebab rendahnya minat masyarakat Rejang Lebong dalam hal ini pelajar kelas 3 SMA yang memilih melanjutkan studi pada Program Studi Ekonomi Syariah IAIN Curup adalah sebagai berikut:

\section{Kurangnya pengetahuan keberadaan Program Studi Ekonomi Syariah IAIN Curup}

Penyebab kurangnya pengetahuan tentang keberadaan Program Studi Ekonomi Syariah IAIN Curup adalah kurangnya informasi mengenai prodi tersebut. Dalam hal ini, Program Studi Ekonomi Syariah IAIN Curup merupakan Program Studi yang baru sehingga masyarakat dalam hal ini para pelajar kelas 3 dilingkungan kabupaten Rejang Lebong masih sangat awam tentang keberadaan prodi tersebut. Bahkan ada beberapa pelajar yang baru pertama mendengar tentang keberadaan Program Studi Ekonomi Syariah IAIN Curup. Selain itu para pelajar tersebut juga masih ragu apa bedanya Program Studi Ekonomi Syariah IAIN Curup dengan program studi lainnya. 


\section{Kurangnya pengetahuan tentang adanya beasiswa Program Studi Ekonomi Syariah IAIN Curup}

Penyebab kurangnya pengetahuan tentang adanya beasiswa Program Studi Ekonomi Syariah IAIN Curup adalah kurang tersebarnya informasi mengenai beasiswa tersebut. Beasiswa yang ada dapat menjadi daya tarik para pelajar untuk memutuskan melanjutkan studi pada Program Studi Ekonomi Syariah IAIN Curup. Namun demikian belum optimalnya penyebaran informasi tentang beasiswa ini sangatlah disayangkan. Berbagai Beasiswa yang ditawarkan pada Program Studi Ekonomi Syariah IAIN Curup misalnya Beasiswa Baznas, Beasiswa Bank Indonesia dan berbagai beasiswa lainnya. Hendaknya manajemen dari Program Studi Ekonomi Syariah IAIN Curup lebih giat lagi dalam menyuarakan tentang beasiswa sebagai poin plus dalam menarik minat para pelajar.

\section{Kurangnya pengetahuan tentang kualifikasi dosen Program Studi Ekonomi Syariah IAIN Curup}

Penyebab kurangnya pengetahuan tentang kualifikasi dosen Program Studi Ekonomi Syariah IAIN Curup yaitu kurang tersebarnya informasi berbagai kualifikasi dosen. Pada Program Studi Ekonomi Syariah IAIN Curup kualifikasi dosen yang mengampu mata kuliah semuanya berasal dari lulusan Magister (S2) dan Doktor (S3) baik dari dalam mapupun luar negeri. Salah satu pertimbangan para pelajar dalam memilih program studi dengan melihat kualifikasi para Dosen yang akan mengajar. Kurangnya pengetahuan tentang kualifikasi dosen ini juga menjadi alasan pelajar tidak memilih Program Studi Ekonomi Syariah IAIN Curup untuk studi lanjutan.

\section{Belum meratanya peserta sosialisasi Visi dan Misi Program Studi Ekonomi Syariah IAIN Curup}

Penyebab belum meratanya peserta sosialisasi Visi dan Misi Program Studi Ekonomi Syariah IAIN Curup yaitu masih terbatasnya dana yang dimiliki Program Studi Ekonomi Syariah IAIN Curup. Berbagai upaya telah dilakukan Program Studi Ekonomi Syariah IAIN Curup untuk melakukan sosialisasi visi dan misi misalnya dengan berkolaborasi dalam acara Otoritas Jasa Keuangan yang diadakan di Perpusktakaan IAIN Curup. Melakukan sosialisasi melalui media sosial. Namun demikian pada pelaksanaan sosialisasi memang membutuhkan dana sehingga pesertanya sosialisasi masih sangat terbatas. 


\section{Kurangnya pengetahuan tentang fasilitas penunjang pada Program Studi Ekonomi Syariah IAIN Curup}

Penyebab kurangnya pengetahuan tentang fasilitas penunjang yaitu kurang tersebarnya informasi berbagai fasilitas penunjang yang dimiliki Program Studi Ekonomi Syariah IAIN Curup. Pada Program Studi Ekonomi Syariah IAIN Curup terdapat fasilitas penunjang dalam perkuliahan misanya terdapat laboratorium yang berisi unit komputer lengkap dan ruangan yang nyaman bagi mahasiswa, adanya LCD sehingga mahasiswa dapat menyerap ilmu pelajaran secara audio dan visual, dan lainnya. Fasilitas penunjang ini menjadi daya tarik sendiri dan juga dapat menjadi referensi dalam memilih program studi.

\section{Kurang tersebarnya informasi tentang proses penerimaan mahasiswa baru Program Studi Ekonomi Syariah IAIN Curup}

Penyebab kurangnya pengetahuan tentang proses penerimaan mahasiswa baru pada Program Studi Ekonomi Syariah IAIN Curup. Pada Program Studi Ekonomi Syariah IAIN Curup setiap awal tahun ajaran baru menerima mahasiswa baru dengan berbagai jalur. Dalam proses penerimaan mahasiswa baru pada Program Studi Ekonomi Syariah IAIN Curup juga ada jalur UM (ujian mandiri) yang diadakan oleh kampus IAIN Curup sehingga memberikan kesempatan bagi masyarakat Kabupaten Rejang Lebong dalam hal ini para pelajar kelas 3 SMA untuk mengikuti proses seleksi ini mengingat lokasinya yang dekat dengan pusat kota.

\section{Kesimpulan}

Berdasarkan hasil pengolahan data penelitian dapat disimpulkan penyebab kurangnya minat masyarakat kabupaten Rejang Lebong dalam hal ini pelajar kelas 12 SMA antara lain sebagai berikut:

Pertama, berdasarkan hasil temuan dilapangan diperoleh kurangnya pengetahuan keberadaan Program Studi Ekonomi Syariah IAIN Curup sehingga diharapkan pihak manajemen Program Studi dapat mengadakan sosialisasi yang intensif sehingga masyarakat mengetahui keberadaan Program Studi Ekonomi Syariah IAIN yang masih baru berdiri.

Kedua, temuan penelitian selanjutnya yaitu kurangnya pengetahuan tentang adanya beasiswa Program Studi Ekonomi Syariah IAIN Curup sehingga diharapkan pihak manajemen Prodi Ekonomi Syariah IAIN dalam 
mensosialisasikan Prodi hendaknya menjelaskan beberapa beasiswa yang bisa diperoleh ketika mereka melanjutkan pendidikan pada prodi Ekonomi Syariah IAINCurup.

Ketiga, hasil temuan berikutnya kurangnya pengetahuan tentang kualifikasi dosen Program Studi Ekonomi Syariah IAIN Curup. sehingga diharapkan pihak manajemen Prodi Ekonomi Syariah IAINCurupdalam mensosialisasikan Prodi hendaknya menjelaskan kualifikasi dosen dari S3 dan S2 baik dalam lulusan negeri maupun luar negeri sehingga meyakinkan masyarakat untuk melanjutkan kuliah pada prodi Ekonomi SyariahIAINCurup

Keempat, temuan selanjutnya belum meratanya peserta sosialisasi Visi dan Misi Program Studi Ekonomi Syariah IAIN Curup sehingga diharapkan dalam acara sosialisasi dipilih perwakilan setiap sekolah pada kabupaten Rejang Lebong agar bisa menjadi perpanjangan tangan untuk menyebarkan informasi mengenai keunggulan Prodi Ekonomi Syariah IAIN Curup.

Kelima, hasil temuan selanjutnya kurangnya pengetahuan tentang fasilitas penunjang pada Program Studi Ekonomi Syariah IAIN Curup sehinggadalam mensosialisasikan Prodi hendaknya menjelaskan adanya fasilitas penunjang proses kegiatan belajar mengajar pada Program Studi Ekonomi Syariah IAIN Curup yang akan menjadi daya tarik masyarakat untuk bergabung menjadi mahasiswa Program Studi Ekonomi Syariah IAIN Curup.

Keenam, temuan terakhir yaitu kurang tersebarnya informasi tentang proses penerimaan mahasiswa baru Program Studi Ekonomi Syariah IAIN Curup sehingga diharapkan pihak manajemen Prodi Ekonomi Syariah IAINCurup turut aktif mensosialisasikan informasi penerimaan mahasiswa baru khususnya bagi calon mahasiswa Prodi Ekonomi Syariah IAINCurup.

\section{Daftar Pustaka}

Ariyani, Luthfina, R. Rizki Amalia, and Yurna Lisa. "Pengaruh Personal Selling Dan Periklanan Terhadap Volume Penjualan Produk Bepang Ud.Diah, Kecamatan PelaiharI.” Jurnal Teknologi Agro-Industri, 2017. https://doi.org/10.34128/jtai.v4i1.48.

Irawan, Agus. "Analisis Pengaruh Bauran Pemasaran Jasa Terhadap 
Keputusan Memilih Program Studi (Studi Pada Jurusan Akuntansi Dan Jurusan Administrasi Bisnis Di Politeknik Negeri Banjarmasin)." Jurnal Wawasan Manajemen, 2014.

Jones, John Philip. "Advertising and Promotion." In Encyclopedia of International Media and Communications, 2003. https://doi.org/10.1016/B0-12-387670-2/00002-9.

Kalsum, Eka Umi. "Pengaruh Strategi Bauran Pemasaran Terhadap Keputusan Mahasiswa Memilih Perguruan Tinggi Swasta Di Medan.” Pengaruh Strategi Bauran Pemasaran Terhadap Keputusan Mahasiswa Memilih Perguruan Tinggi Swasta Di Medan, 2010.

Kotler. Manajemen Pemasaran Jilid 2. Penerbit Erlangga, 2013.

Moleong, Lexy J. "Metodologi Penelitian Kualitatif (Edisi Revisi)." In PT. Remaja Rosda Karya, 2017.

P. Ginting, B. Sembiring D. Gultom. "Pengaruh Bauran Pemasaran Jasa Dan Kualitas Pelayanan Terhadap Mahasiswa Program Studi Manajemen Fakultas Ekonomi Universitas Muhammadiyah Sumatera Utara." Manajemen Dan Bisnis, 2014.

Parasuraman, A., Valarie A. Zeithaml, and Leonard L. Berry. "A Conceptual Model of Service Quality and Its Implications for Future Research." Journal of Marketing, 1985. https://doi.org/10.2307/1251430.

Quodri Wijaya, Nur. "Strategi Untuk Meningkatkan Minat Mahasiswa Baru Studi Pada Universitas Wiraraja Sumenep." Journal of Chemical Information and Modeling, 2013. https://doi.org/10.1017/CBO9781107415324.004.

Susilo, Heri; Haryono, Andi Tri; W, Moh Mukery. "Analisis Pengaruh Harga, Kualitas Pelayanan, Promosi, Dan Kepercayaan Terhadap Kepuasan Konsumen Dengan Keputusan Berkunjung Sebagai Variabel Intervening Di Hotel Amanda Hills Bandungan." Maharaja Agrasen Institute of Management and Technology Journal of IT \& Management, 2018.

Swastha, Basu, Irawan. Manajemen Pemasaran Modern.Liberty, Yogyakarta., 2014. https://doi.org/10.1017/CBO9781107415324.004.

Tjiptono, Fandy. "Pemasaran Jasa - Prinsip, Penerapan, Dan Penelitiab." In 1, 2014.

Tjiptono, Fandy, and Fandy Tjiptono. "Service Management: Mewujudkan Layanan Prima / Fandy Tjiptono." ,Service Management: Mewujudkan Layanan Prima / Fandy Tjiptono, 2012. 
138 | FOKUS : Jurnal Kajian Keislaman dan Kemasyarakatan Vol. 5, No. 1, 2020

https://doi.org/10.1519/JPT.0b013e31826e7d33.

Wariki, Grace, Lisbeth Mananeke, and Hendra Tawas. "Pengaruh Bauran Promosi, Persepsi Harga Dan Lokasi Terhadap Keputusan Pembelian Dan Kepuasan Konsumen Pada Perumahan Tamansari Metropolitan Manado." Jurnal Riset Ekonomi, Manajemen, Bisnis Dan Akuntansi, 2015. https://doi.org/10.35794/emba.v3i2.9286.

Widyahening, Christiana Evy Tri. "Penggunaan Teknik Pembelajaran Fishbone Diagram." Jurnal Komunikasi Pendidikan, 2018. https://doi.org/https://doi.org/10.32585/jkp.v2i1.59. 